\title{
The contribution of drinking water fluoride to the risk of dental fluorosis in Estonia
}

\author{
E. Indermitte ${ }^{1,2}$, A. Saava ${ }^{1}$, S. Russak ${ }^{3}$ \& A. Kull ${ }^{2}$ \\ ${ }^{I}$ Department of Public Health, University of Tartu, Estonia \\ ${ }^{2}$ Institute of Geography, University of Tartu, Estonia \\ ${ }^{3}$ Department of Stomatology, Tartu University Clinicum, Estonia
}

\begin{abstract}
Fluoride is one of the few chemicals of natural origin that have been shown to cause significant health effects in people through drinking-water. The association between the fluoride level in drinking water and the degree of dental fluorosis has been documented worldwide. The permissible maximum health-based fluoride limit in drinking water is $1.5 \mathrm{mg} / \mathrm{l}$. The aim of this paper is to assess human exposure to drinking water fluoride in Estonia and determine the contribution of drinking water fluoride content to the dental fluorosis risk. The paper is based on the survey of drinking water supply in Estonia drawn from the database of the National Health Protection Inspectorate and supplemented by a special study to determine the fluoride content of water in public water supplies all over Estonia. The retrospective case study to determine the risk of fluorosis was carried out. The subjects of the study were 12 years old, living in six districts of the town of Tartu with different fluoride content in drinking water. In total 368 children were investigated. Fluoride content in the drinking water of the Estonian population varied in a large scale. The permissible maximum limit was exceeded in $14.4 \%$ of water samples. High levels of fluoride are due to a natural geogenic source. The proportion of the population exposed to a high fluoride level in drinking water was small (4.2\%), mainly consumers of small water supply systems in West-Estonia, where the only drinking water source is the Silurian-Ordovician aquifer system. Association between prevalence of dental fluorosis among 12-year old schoolchildren and fluoride content in drinking water was observed. The obtained data allowed the assessment of the risk of dental fluorosis for the Estonian population. Control of drinking water quality is critical in preventing fluorosis.
\end{abstract}

Keywords: drinking water, Estonia, fluoride, fluorosis, health risks. 


\section{Introduction}

Levels of chemicals in environmental media and population exposure to these levels are critical to protect public health from environmental health risks [1]. Fluoride is one of the few chemicals of natural origin that has been shown to cause significant effects in people through drinking-water. The long-term moderate-level chronic exposure to fluoride in drinking-water at or over the current WHO guideline value $(1.5 \mathrm{mg} / \mathrm{l})$ can cause incurable but potentially preventable fluorosis which affects the teeth and bones [2]. The association between fluorides in drinking water and the degree of dental fluorosis has been documented worldwide [2-4]. Dental fluorosis is characterized by staining and pitting of the teeth. In more severe cases, all the enamel may be damaged. Millions of people around the world both in developing and developed countries are exposed to excessive amounts of fluoride through drinking water contaminated from natural geological sources. As a result, many suffer conditions ranging from mild dental fluorosis to crippling skeletal fluorosis. Therefore, the control of drinking water quality is critical in preventing dental diseases.

In Estonia groundwater from several aquifers is the main drinking water source in most towns and rural settlements. Fluoride concentrations in ground water were found to vary in a large range: from 0.01 to $6.95 \mathrm{mg} / 1$ [5]. Since drinking water is typically the most significant source of fluoride [2] an in depth exposure assessment to fluoride is urgently called for.

On the other hand, health problems arising from different fluoride levels in drinking water have been detected in Estonia [6]. Faced with an incurable but preventable condition (fluorosis) from fluorides in drinking water, the risk of fluorosis due to high fluoride levels in drinking water is an irrefutable argument for risk assessment on fluorides in drinking water.

\section{Materials and methods}

\subsection{Study area}

Estonia is the smallest Baltic country with an area of $45.227 \mathrm{~km}^{2}$ and population of 1.351 (01.01.2004) million people, situated on the East coast of the Baltic Sea and lying in North-western part of the East-European Platform. Administratively Estonia is divided into 15 counties (Figure 1). 82.9\% of Estonian population is well provided with public water supplies, what is a very high share if we will consider that urban population makes up to $69.3 \%$ of population and rural population $(30.7 \%)$ is highly scattered with average population density of $10.5 \mathrm{in} / \mathrm{km}^{2}$. There are 1233 public water supplies in the country. The prevalence of small water supplies is characteristic for Estonia. Up to $86 \%$ of supplies serve less than 500 inhabitants [5].

Deep groundwater of several aquifers abstracted by drilled tube wells in towns and rural settlements is the main source of drinking water. Five aquifer systems are exploited depending on location (Middle-Devonian, Middle-Lower- 
Devonian, Silurian-Ordovician, Ordovician-Cambrian and Cambrian-Vendian). They differ from each other in distribution and chemical composition [7]. The groundwater is used directly without treatment. In two towns (capital Tallinn and Narva) surface water after treatment and disinfection is used as main source of drinking water.
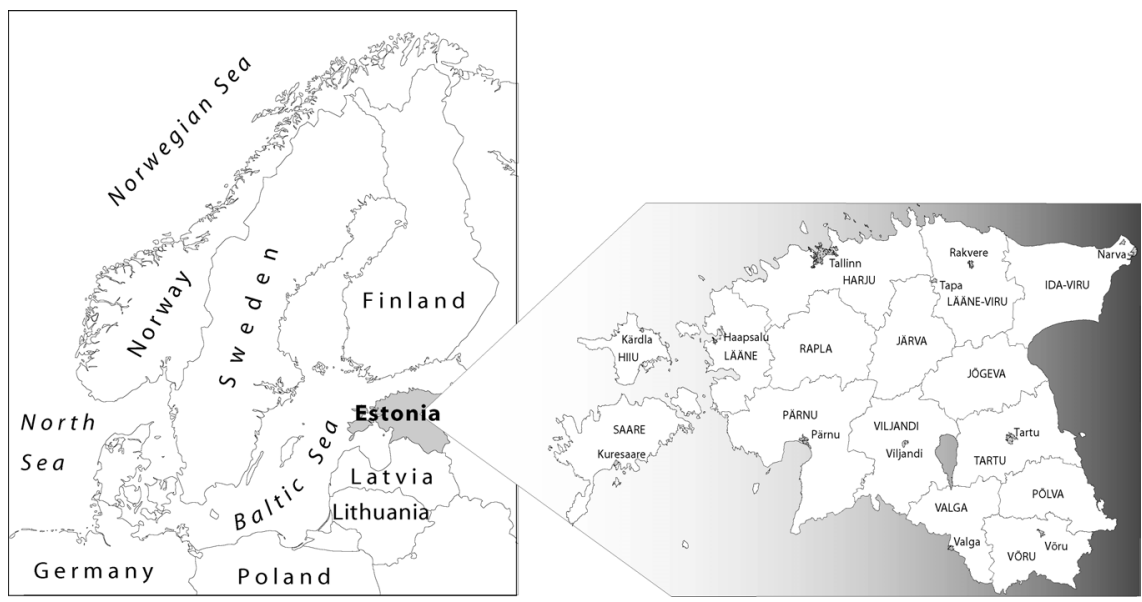

Figure 1: $\quad$ Location of study area.

\subsection{Exposure data}

The determination of fluoride content in drinking water of inhabitants of the whole of Estonia was performed in 2004. Data on access of population to water supplies and number of water consumers by supplies were obtained from Estonian Health Protection Inspectorate database on drinking water "JVESI". All water supplies serving at least 100 consumers were visited and the sites for sampling were selected. In case the supply system operated several drilled tube wells, additional samples were taken from different locations according to the influential area of the wells. Altogether 735 samples were collected in 47 towns and 471 rural settlements in all 15 counties throughout Estonia.

Water samples for fluoride analyses were collected from tap water closest to the consumer. The analyses were carried out according to the Standards Methods for the Examination of Water and Wastewater by the SPADNS colorimetric method during 48 hours [8].

The results of analyses were grouped into 3 categories according to the health effects of fluoride level in water:

1) high-fluoride content drinking water (over $1.50 \mathrm{mg} / \mathrm{l}$ ) - causing adverse health effects (primarily dental fluorosis);

2) medium-fluoride content drinking water $(0.51-1.50 \mathrm{mg} / \mathrm{l})$ - having protection against dental caries with the least risk of producing dental fluorosis or other toxic effects;

3) low-fluoride content drinking water (up to $0.50 \mathrm{mg} / \mathrm{l}$ ) - insufficient to prevent caries. 


\subsection{Case study}

A special retrospective case study to determine the contribution of drinking water fluoride to the dental fluorosis risk (odds ratio - OR) was carried out among 12-year old schoolchildren who were born and living in Tartu city where the content of fluoride in drinking water varies by regions. Tartu is the second largest city in Estonia, covering an area of $39 \mathrm{~km}^{2}$ with the population of 101740 inhabitants. The groundwater without any treatment is used to supply drinking water. Over 100 drilled deep tube wells are connected to the public water supply network. They rely on Devonian, Silurian and Ordovician-Cambrian hydrogeological aquifers with different quality of water. The data on fluoride concentration in water were obtained from the water quality database of drilled tube wells in 1986-1997 compiled for the Tartu Agenda 21 [9]. Since the municipal drinking water distribution system combines water from several groundwater aquifers, the fluoride concentration in tap water at consumer varies depending on the district of the influence of the tube well. For the study we took care to select only districts that were supplied by definite tube wells of known fluoride concentration. In result six districts were defined purposively for the study (Figure 2). These districts are of approximately the same ecoenvironmental and ethnic conditions as well as socioeconomic standards.

The sampling population was a part of the over-Estonian survey of dental health of schoolchildren conducted in 1999-2000 according to the uniformed methodology of World Health Organisation [10]. The 12-year old children served as a target group. Consent from the children, as well as from local authorities was obtained prior to examination. The children were asked about the duration of their residence at the present address. Schoolchildren were localized according to their current home address and their correspondence to drinking water districts was determined. Only those schoolchildren who had reported continuous residence since birth in corresponding districts were included in the study. As a result the total sample size was 368 children.

Clinical intra-oral examination was conducted at the schools by a trained examiner with an assistant recording the observations. Dental fluorosis was assessed on vestibular, occlusal and lingual surfaces. The white flecks, fine white and brown lines in the enamel were registered as a mild degree of fluorosis. Very chalky, opaque enamel, mottling and loss of portions of the outer enamel were diagnosed as severe fluorosis.

Data was digitized using Excel programme and a Statistical Package for Social Science (SPSS 10.0 for Windows). The prevalence of dental fluorosis was calculated as frequency of occurrence among study population (\%). The risk of dental fluorosis was expressed as the odds ratio of disease (OR).

\section{Results}

\subsection{Exposure of population to fluorides through drinking water}

Fluoride content in drinking water in Estonia varied on a large scale: 0.01$6.95 \mathrm{mg} / \mathrm{l}$ with a mean of $0.88 \pm 0.90 \mathrm{mg} / \mathrm{l}$. In $306(41.6 \%)$ samples the fluoride 
content was low $(<0.5 \mathrm{mg} / \mathrm{l})$. Medium concentrations $(0.5-1.5 \mathrm{mg} / \mathrm{l})$ were measured in $323(44.0 \%)$ samples. The Estonian national limit - $1.5 \mathrm{mg} / \mathrm{l}$ - was exceeded in $106(14.4 \%)$ samples. Fluoride content in drinking water varied greatly both between and within counties (Table 1).

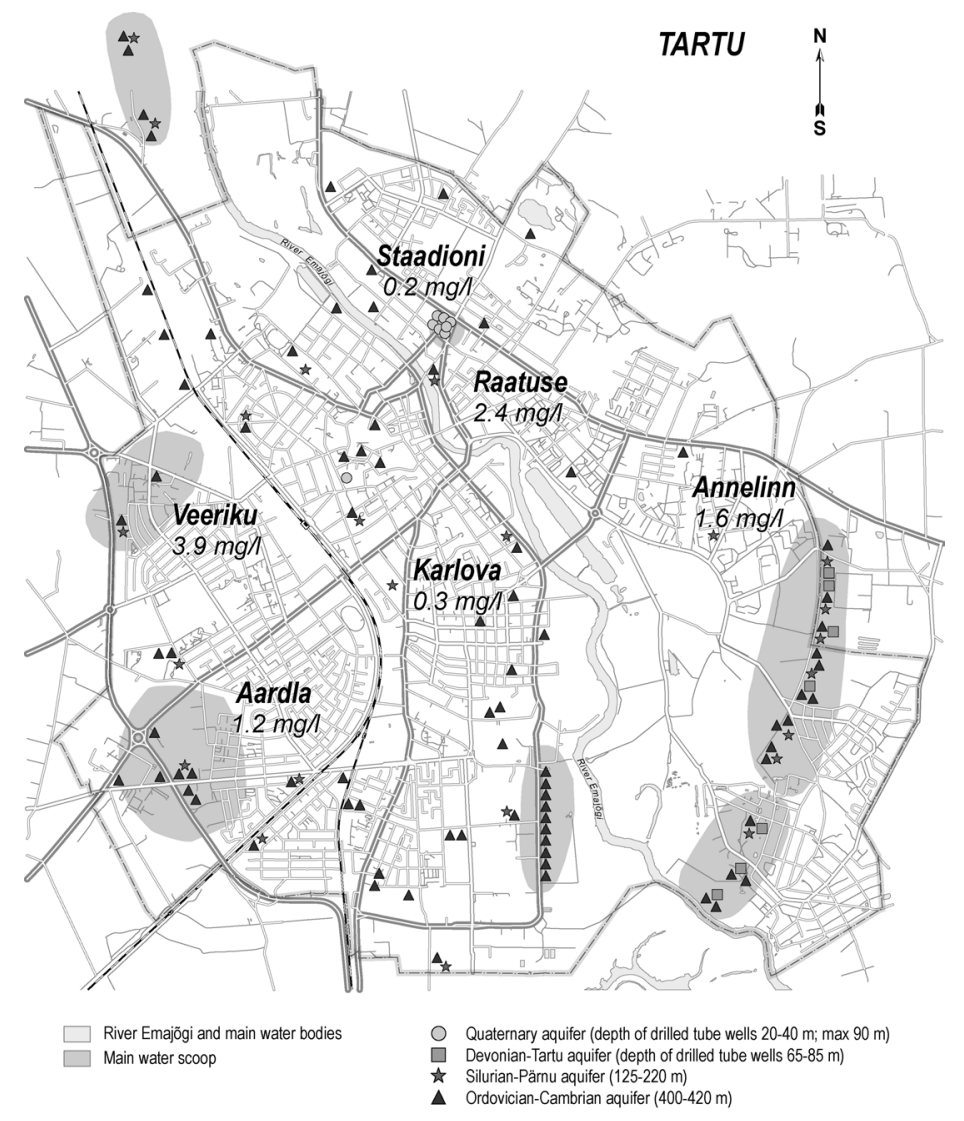

Figure 2: $\quad$ Location of Tartu districts covered by retrospective case study.

The exposure analysis revealed that only $38.1 \%$ of study population (400 040 inhabitants) was consuming water with medium fluoride concentration, lowfluoride water was consumed by 57.8\% (607 544 in) and high-fluoride water by $4.1 \%$ (42 $571 \mathrm{in}$ ) of the study population. The situation differed to a large extent in different towns and counties. The population of Tallinn (396 000 in) and Narva (68 000 in) used mainly surface water with naturally very low fluoride content. The second largest city Tartu (101 000 in) was provided mainly with medium-fluoride water. While most of the population (over 60\%) in Harju, Pärnu, Saare, Hiiu, Viljandi and Lääne counties was exposed to medium-fluoride water, the whole population in Võru county (100\%) was exposed to low-fluoride water. Over half of population was consuming low-fluoride water also in Valga, 
Järva and Põlva counties. Most of people consuming high-fluoride water were living in Pärnu county, followed by people in Rapla, Tartu, Järva and Lääne counties. The main risk from consuming high-fluoride water is dental fluorosis, but also other toxic effects of fluorides are of serious concern $[2,11]$.

Table 1: Approximate number of people consuming drinking water with different levels of fluoride in 2004 by counties.

\begin{tabular}{|l|r|r|r|r|r|}
\hline \multirow{2}{*}{$\begin{array}{c}\text { Name of } \\
\text { county }\end{array}$} & $\begin{array}{c}\text { Number } \\
\text { of water } \\
\text { samples }\end{array}$ & $\begin{array}{c}\text { Range of } \\
\text { fluoride } \\
\text { content } \\
\text { mg/l }\end{array}$ & \multicolumn{3}{|c|}{$\begin{array}{c}\text { Number of people consuming } \\
\text { drinking water with different } \\
\text { fluoride level }\end{array}$} \\
\cline { 3 - 6 } & & \multicolumn{1}{c|}{$\begin{array}{c}\text { Low- } \\
\text { fluoride }\end{array}$} & $\begin{array}{c}\text { Medium- } \\
\text { fluoride }\end{array}$ & $\begin{array}{c}\text { High- } \\
\text { fluoride }\end{array}$ \\
\hline Harju & 119 & $0.01-2.06$ & 364979 & 86324 & 3978 \\
\hline Hiiu & 17 & $0.38-1.92$ & 50 & 5372 & 1228 \\
\hline Ida-Viru & 48 & $0.21-1.29$ & 108207 & 57952 & 0 \\
\hline Jõgeva & 38 & $0.06-3.28$ & 9125 & 8267 & 1571 \\
\hline Järva & 49 & $0.05-3.12$ & 16621 & 3560 & 5026 \\
\hline Lääne & 29 & $0.54-5.60$ & 0 & 13965 & 4110 \\
\hline Lääne-Viru & 65 & $0.10-1.81$ & 21370 & 29884 & 225 \\
\hline Põlva & 31 & $0.08-1.10$ & 9835 & 5885 & 0 \\
\hline Pärnu & 63 & $0.08-6.95$ & 980 & 44765 & 8562 \\
\hline Rapla & 42 & $0.12-3.68$ & 4667 & 12901 & 5354 \\
\hline Saare & 28 & $0.22-5.50$ & 1360 & 18805 & 2140 \\
\hline Tartu & 73 & $0.10-3.48$ & 27165 & 81165 & 5222 \\
\hline Valga & 30 & $0.06-1.58$ & 17303 & 1247 & 1500 \\
\hline Viljandi & 56 & $0.05-2.56$ & 4621 & 29948 & 3655 \\
\hline Võru & 47 & $0.08-0.45$ & 21261 & 0 & 0 \\
\hline Total & $\mathbf{7 3 5}$ & $\mathbf{0 . 0 1}-\mathbf{6 . 9 5}$ & $\mathbf{6 0 7 5 4 4}$ & $\mathbf{4 0 0 ~ 0 4 0}$ & $\mathbf{4 2 5 7 1}$ \\
\hline
\end{tabular}

\subsection{Dental fluorosis risk}

The dental fluorosis risk (odds ratio - OR) was studied among 12-year-old schoolchildren who were born and living in Tartu city where content of fluoride in drinking water varies in a large scale by districts depending on the water source (groundwater aquifer) from which the supply system feeds on.

Table 2 represents the mean value, standard deviation and range of fluoride content in drinking water sources (tube wells) by the study districts in 19861997. It is the period when the study population was born and grown up.

The distribution of study subjects according to residence in six districts and prevalence of dental fluorosis is shown in the same Table 2.

The number of children was different by districts. Boys and girls were equally represented in the total sample ( $47 \%$ and $53 \%$, respectively). The prevalence of dental fluorosis among Tartu schoolchildren was $30.2 \%$, being $26.3 \%$ among boys and $33.7 \%$ among girls. The difference between boys and girls was not 
statistically significant. In most cases $(89 \%)$ the mild degree of fluorosis was diagnosed. Only twelve children ( 3 boys and 9 girls) had severe fluorosis. They lived in the high-fluoride districts.

Results obtained by districts showed that the percent of children with dental fluorosis increased with the increase of fluoride content in the drinking water source (Table 2). Strong association between water fluoride level and prevalence of fluorosis allowed the calculation of the odds ratio (OR) of dental fluorosis in relation to district of residence and the fluoride content in the drinking water (Table 3).

The risk of dental fluorosis was over 6 times higher among children of Annelinn district (IV) where the average fluoride content exceeded the permissible level as compared to Staadioni district (I). In districts V and VI the risk was even higher. Currently, the wells producing high-fluoride water are excluded from the public water supply system. In districts II and III where the fluoride content in water was below the limit, there was no significant risk of dental fluorosis as compared to district I where the fluoride content in water was the lowest.

Table 2: $\quad$ Fluoride content $(\mathrm{mg} / \mathrm{l})$ of drinking water sources in Tartu, 19861997 and prevalence of dental fluorosis among 12-year old schoolchildren.

\begin{tabular}{|c|c|c|c|c|c|c|}
\hline \multicolumn{2}{|c|}{ District } & \multirow[t]{2}{*}{$\begin{array}{c}\text { No of } \\
\text { water } \\
\text { samples }\end{array}$} & \multicolumn{2}{|c|}{$\begin{array}{l}\text { Fluoride content in } \\
\text { water }(\mathrm{mg} / \mathrm{l})\end{array}$} & \multirow[t]{2}{*}{$\begin{array}{l}\text { No of } \\
\text { children }\end{array}$} & \multirow{2}{*}{$\begin{array}{l}\text { Children } \\
\text { with } \\
\text { fluorosis } \\
\text { No / \% }\end{array}$} \\
\hline No & Name & & mean & range & & \\
\hline I & Staadioni & 25 & 0,18 & $0,10-0,30$ & 34 & $3 / 8,8$ \\
\hline II & Karlova & 20 & 0,29 & $0,10-0,70$ & 38 & $6 / 15,8$ \\
\hline III & Aardla & 28 & 1,19 & $0,80-1,50$ & 100 & $21 / 21,0$ \\
\hline IV & Annelinn & 35 & 1,59 & $1,30-1,90$ & 149 & $57 / 38,3$ \\
\hline $\mathrm{V}$ & Raatuse & 24 & 2,41 & $1,85-3,20$ & 17 & $8 / 47,1$ \\
\hline \multirow[t]{2}{*}{ VI } & Veeriku & 8 & 3,89 & $3,35-4,40$ & 30 & $16 / 53,3$ \\
\hline & Total & 140 & 1,34 & $0,10-4,40$ & 368 & $111 / 30,2$ \\
\hline
\end{tabular}

Table 3: $\quad$ Risk of dental fluorosis among schoolchildren in different districts of Tartu (compared to Staadioni district).

\begin{tabular}{|c|c|c|c|c|}
\hline $\begin{array}{c}\text { No of } \\
\text { district }\end{array}$ & $\begin{array}{c}\text { Name of } \\
\text { district }\end{array}$ & $\begin{array}{c}\text { Content of fluoride } \\
\text { in water mg/l }\end{array}$ & Odds ratio & $\begin{array}{c}\text { Confidence interval } \\
\text { (CI 95\%) }\end{array}$ \\
\hline I & Staadioni & 0,2 & 1,00 & \\
\hline II & Karlova & 0,3 & 1,94 & $0,37-12,91$ \\
\hline III & Aardla & 1,2 & 2,75 & $0,73-15,30$ \\
\hline IV & Annelinn & 1,6 & $\mathbf{6 , 4 0 *}$ & $1,85-33,95$ \\
\hline V & Raatuse & 2,4 & $\mathbf{9 , 1 8 *}$ & $1,66-61,76$ \\
\hline VI & Veeriku & 3,9 & $\mathbf{1 1 , 8 1}^{*}$ & $2,65-70,32$ \\
\hline
\end{tabular}

* statistically significant. 


\section{Discussion}

The research approach and sampling scheme of this study was designed to evaluate Estonian population exposure to fluoride from drinking water and assess the contribution of drinking water fluoride to dental fluorosis. This study cannot comment on overall exposure to fluoride, although drinking water is usually the largest contributor to fluoride intake $[2,12]$.

The study covered all 15 counties in Estonia embracing $93.7 \%$ of population having access to public water supplies. The overall access to public water supplies was $82.9 \%$, but the variation between cities and rural settlements is large [5]. The prevalence of a large number of small water supplies complicates the improvement of water quality.

Groundwater is the most important source of drinking water. Only few studies on occurrence and distribution of fluoride in groundwater have been carried out in Estonia [13-15]. Quite often the tap water originates from different sources and is mixed in water supply systems. Our data from the analysis of drinking water samples collected throughout Estonia provide the necessary information for assessment of human exposure to fluoride.

Based on current study, the great majority (about 96\%) of Estonian population was drinking water with fluoride below $1.5 \mathrm{mg} / \mathrm{l}$. Over half $(57.8 \%)$ of population was exposed to water containing very low fluoride levels (up to $0.5 \mathrm{mg} / \mathrm{l})$. Only $4.1 \%$ of the population was exposed to high-fluoride content (over $1.5 \mathrm{mg} / \mathrm{l}$ ) drinking water. Nearly 4000 people was exposed to very high fluoride levels (over $4.0 \mathrm{mg} / \mathrm{l}$ ). They lived mainly in West Estonia (Lääne, Rapla and Pärnu counties), where the only drinking water source is Silurian-Ordovician aquifer system. The high levels of fluoride are due to geogenic sources [13].

Elevated fluoride concentrations were also found in some water supplies of central Estonia (Tartu, Viljandi and Järva counties). This is the area where hydraulically connected Devonian and Silurian strata form the Devonian-Silurian aquifer system. The content of fluoride is related with the depth of the wells [13].

The prevalence of dental fluorosis among schoolchildren was studied in Tartu where the fluoride content in drinking water varied between districts significantly. Other conditions (climate, quality of outdoor air, living conditions, dietary habits and oral hygiene) were considered to be distributed evenly inside the city. This study assumed that the fluoride exposure of each child in the district corresponded to the average fluoride level in drinking water of that district. Because of the lack of resources it was not possible to determine the individual exposure of subjects via drinking water.

The present results and those of previous studies [6] strengthen the notion that there is a systematic and positive relationship between the fluoride content in drinking water and the prevalence of dental fluorosis. It has been determined that fluoride concentration in excess of $1.6 \mathrm{mg} / \mathrm{l}$ and over exposes residents to high fluorosis risk quantified as odds ratio. 


\section{Conclusions}

This study provides an overview of the fluoride content in drinking water and the extent of human exposure to different levels of fluoride through drinking water for the whole of Estonia. As drinking water is usually the main source of fluoride intake, the levels of fluoride in tap water is very important in determining total fluoride exposure.

Human exposure analysis revealed that majority of people (about 96\%) consumed water with a fluoride content below the maximum permitted level $(1.5 \mathrm{mg} / \mathrm{l})$. Very small portion of population $(4.1 \%)$ was exposed to high-fluoride drinking water. Very high naturally occurring fluoride concentrations (up to 7 $\mathrm{mg} / \mathrm{l}$ ) were common in West Estonia where the main drinking water source is the Silurian-Ordovician aquifer system.

A systematic and positive relationship between the prevalence of dental fluorosis and the exposure to fluoride through drinking water was determined. The fluoride in excess of $1.6 \mathrm{mg} / \mathrm{l}$ in drinking water increased the dental fluorosis risk over 6 times. The information of population about the levels of fluoride in drinking water is an important key element in health risk prevention.

The results of the current study as well as other available data from water quality should be taken into account when developing strategies for safe drinking water supplies.

\section{Acknowledgements}

This study has been supported by the Target Funding Projects No. 0180052s07 and No. $0182648 \mathrm{~s} 04$ of the Ministry of Education and Science of Estonia and by Estonian Society of Stomatology.

\section{References}

[1] Pirkle, J.L., Osterloh, J., Needham, L.L. \& Sampson, E.J., National exposure measurements for decisions to protect public health from environmental exposures. Int. J. Hyg. Environ. Health, 208(1-2), pp. 1-5, 2005.

[2] Farwell, J., Bailey, K., Chilton, J., Dahi, E., Fewtrell, L. \& Magara, Y., Fluoride in drinking-water. World Health Organization (WHO), IWA Publishing, London-Seattle; 2006.

[3] Angelillo, I.F., Torre, I., Nobile, C.G. \& Villari, P., Caries and fluorosis prevalence in communities with different concentrations of fluoride in water. Caries Res., 33(2), pp. 114-122, 1999.

[4] Moturi, W.K., Tole, M.P. \& Davies, T.C., The contribution of drinking water towards dental fluorosis: a case study of Njoro Division, Nakuru District, Kenya. Environ. Geochem. Health, 24, pp. 123-130, 2002.

[5] Indermitte, E., Saava, A. \& Kull, A., The survey of drinking water supply in Estonia from the point of view of public health. The Sustainable City IV. Urban Regeneration and Sustainability, eds. U. Mander, C.A. Brebbia 
\& E. Tiezzi, Wessex Institute of Technology Press: Southampton, Boston, pp. $817-826,2006$.

[6] Saava, A., Health hazards due to drinking water. Proc Latvian Acad Sci 52, eds. I. Rašals et al, Latvian Academy of Sciences: Riga, pp. 162-167, 1998.

[7] Karise, V., Metsur, M., Perens, R., Savitskaja, L. \& Tamm, I. Eesti põhjavee kasutamine ja kaitse [Use and protection of groundwater in Estonia]. Eesti Põhjaveekomisjon: Tallinn (in Estonian), pp. 81, 2004.

[8] APHA, Standard methods for the examination of water and wastewater, $2^{\text {nd }}$ edn., American Public Health Association: Washington, DC, 1998.

[9] Alakivi, U., Frey, T., Maastik, A. \& Mander, U., (eds). Tartu Agenda 21, Tartu, 1999.

[10] WHO, Oral Health Surveys. Basic Methods. $4^{\text {th }}$ ed, World Health Organisation: Geneva, 1997.

[11] Colquhoun, J., Why I changed my mind about fluoridation. Fluoride, 31, pp. 103-18, 1998.

[12] Erdal, S. \& Buchanan, S.N., A quantitative look at fluorosis, fluoride exposure, and intake in children using a health risk assessment approach. Environ. Health Persp, 113(1), pp. 111-117, 2005.

[13] Karro, E. \& Rosentau, A., Fluoride levels in the Siluarian-Ordovician aquifer system of western Estonia. Fluoride, 38(4), pp. 307-311, 2005.

[14] Kuik, L., Joogivee fluori- ja joodisisaldus Eesti NSV-s [Fluoride and iodine content of drinking water in Estonian SSR]. Kurortoloogilised Uurimised, 2, pp. 39-45 (in Estonian), 1963.

[15] Karro, E., Indermitte, E., Saava, A., Haamer, K., Marandi, A. Fluoride occurrence in publicly supplied water in Estonia. Environmental Geology, 50(3), pp. $389-396,2006$. 